\author{
Chloe Delen \\ Student of France University IESEG School of Management \\ Email: chloe.delen@ieseg.fr \\ Tetyurenko Angelina \\ 4th year student, Faculty "International School of Business and the World Economy» \\ Plekhanov Russian University of Economics, \\ Russian Federation, 117997, Moscow, Stremyanny lane, 36 \\ E-mail: angelina.tetiourenko@gmail.com \\ Glubokova Nadezhda Yuryevna \\ Ph.D., Associate professor, Department of Accounting and Taxation \\ Plekhanov Russian University of Economics, \\ Russian Federation, 117997, Moscow, Stremyanny lane, 36 \\ Email: glubokova@mail.ru
}

\title{
EDUCATIONAL SYSTEM IN FRANCE AND CAREER DEVELOPMENT OPPORTUNITIES
}

Summary. The article considers the French educational system. Author analyses the history and peculiarities of French education development, and evaluates it in comparison with other European countries and Russia. They pay attention to the right of education for women, stopped at the characteristics of education on each of it stage: from primary school, moving to the middle school till high school, and at the end on the CAP. They make an important conclusion, that French's education system has much common with other EU nations, what permits the students from the European Union to find a job quicker in any of the twenty eight countries due to the fact that the systems resemble one another.

Keywords: educational system, France, career, education, demography, sociological statistics

Introduction. Years of fight were necessary in order to obtain the right to education for every girl and boy of any social class. It is during the 20th century that mentalities begin to change and the obligatory and then prolonged schooling of girls, gradually throughout the century, led young girls to equal knowledge [1, 2]. However, education has never been as much at the centre of concerns of the developed countries, knowing that an instructed population is the key to the prosperity of the economy. Therefore, today, we will be looking at the French educational structure, its particularities and then evaluate it on a European scale. In a last part, we will consider the potential career development opportunities for foreigners in France.

Main body. Like in many other countries, the obtaining of the right of education was a long fight for French women. In 1905, a new law declared the separation of the Church and the State, and thus marked the end of the religious education. However, still today, some private schools give classes of catechism (teach- ing of Catholicism). During Renaissance period, only the girls from a high social class family could attend personal lessons of literature, history and languages. The law "Falloux" in 1850 made compulsory the construction of a primary school for girls in every town or city of more than 800 inhabitants. Finally, during the III Republic, new scholar laws were passed (1881-1882), by the initiative of Jules Ferry, pioneer of the access to free education for everyone $[2,3]$.

These legislative measures permit to teach the basis of calculus, writing, reading to the girls who were discriminated all these years. In 1959, education becomes compulsory until 16 years old, after obtaining the "Brevet des Colleges", diploma certifying the studies of the pupil just before integrating High School. Today, there are 65000 -scholar institutions with both public and private schools in France. The majority (78.5\% according to Eurostat in 2011) of French students are enrolled in a public school, which is free and thus financed by the French state. The peculiarity of 
private institutions $(21.5 \%$ of students) is that a lower number of students permits a better supervision of the students and a better quality of teaching (however, students have to pay educational fees).

Education in France starts at 3 years old, in kindergarten. After that, children enter primary school aged 6 , and study for five years. At the end of the primary school, children pass a test, which will permit them to access middle school $[4,5]$. This test evaluates the overall competencies of the children in reading, writing and mathematics. According to the grades, students can access a more or less prestigious middle school [6]. This middle school lasts for four years and aims to teach the students a broad range of subjects, from history and geography to mathematics, French and English languages and another foreign language (students have a choice between Spanish and German), arts, information technology, technology, music, sports, sciences and chemistry. Students can also choose option courses during their scholarship, such as Latin and ancient Greek.

The end of the middle school is marked by a national examination named "Brevet des colleges", evaluating the different subjects of these four years of teaching providing general knowledge, and permits to the student to access High School. Integrating High School, students can choose between three general tracks: Scientific, Economics and Social and Literature. Subjects are then different according to the specialization chosen.

Students have to solve three tasks to pass a French national examination in second year of high school. The grade required to obtain the final examination in last year (year 3) of High School is 10 out of 20 points; which is a cumulative of the grades obtained in all the subjects. Better the grade and higher will be the chances for the students aiming to the pursuit of their studies in the superior to enter a highly ranked university.

Finally, students can do a CAP, which is a diploma, preparing the students to integrate the labor market in two years (e.g. of job: baker, manual jobs). These specialized tracks are less prestigious, and thus the majority of the students (65\%, according to the ministry of national education and youth) choose the general track permitting them to access to the higher education system.

Students having obtained their baccalaureate (end of high school diploma), are eligible to enter a university or private school. The majority of students apply for their studies of choice through a website called "parcour-sup", ranging the majority of the French universities. Students need to provide their grades and are then ranked according to them. Therefore, the best students will obtain their first choice of university and the students with lower grades will obtain not so good option. It is also possible to pass a competition exam (several according to the school you want to join), which is a popular way of entry in business and engineering schools. Finally, the students that obtained extremely good grades in High School can join a "prepa" which is a two-year program of intense preparation of cultural knowledge in many different subjects. At the end of these two years, students pass an examination and are ranked according to their grades. Students choosing this track in order to reach the very best universities in the world. However, competition is high and many students fail to stay in the program for the two years.

According to Eurostat data, the most popular studies after the BAC are medicine studies, Law, Business and Journalism (private schools) with $35 \%$ of enrolment. In addition, $16 \%$ of French students engage in engineering and $14 \%$ in health and social activities [7, 8]. There is a drastic rise in the number of students continuing their studies after high school, with an increase in every track, especially in technological university institutes (IUT), engineering, medicine and business schools in which the effectives of students more than doubled or even tripled in thirty-six years.

In order to prevent youngsters in scholarship difficulties from social exclusion, specialized organisms have emerged all over France permitting to mentor these pupils with psychomotor handicaps. One of these associations is Apprentices d'auteuil, which offers accompanying programs adapted to each student profile, from kindergarten to the fifth grade. Apart from mentoring in special establishments, students with lighter handicap problems can have a personal tutor who helps the student while at school and/or to do his homework at home.

Foreigners constitute $12,5 \%$ of individuals on the labor market per year during the decade of 1990 . According to INSEE, since 1995, the proportion of immigrates aged under 30 has diminished whereas the proportion of immigrates over 60 years old has increased, which makes us observe an ageing phenomenon linked to the hardening of immigration policies [9].

However, when the qualifications of a French person and a foreign person are equivalent, the remuneration levels are pretty similar according to Inslee. However, the access to the labour market remains more difficult for foreigners, including certain occupations concerning national sovereignty (police, armed forces) or in law, which accesses are prohibited. A solution to counter these barriers to employment is naturalization, permitting to obtain the French nationality in a couple of years. Moreover, for foreigners outside the European Union, administrative formalities are necessary to 
obtain an authorization of work, in order to be able to work in France. This is why the closure of the French labor market remains strong compared to other countries.

In spite of this, foreigners have some advantages in integrating themselves into the course of French work, in particular the knowledge of a foreign language, which, in the context of the internationalization of enterprises and the conquest of new economic markets, remains an essential knowledge. Finally, an example of a country with a strong migration flow is Romania, where 3.4 million people (17\% of the population) has left the country between 2007 and 2017 [10].

The main reason for this mass exodus is the search for super incomes for Romanians, especially in the health sector. In France, $11.8 \%$ of practicing physicians are foreigners. It can be seen that this brain drain is benefiting France, which has a shortage of medical personnel. Therefore, medicine is a highly recruiting area for foreigners.

However, things are changing rapidly and as we come closer to 2022, a progression in the highly qualified jobs is noticed whereas a decline in jobs of workers is expected. Moreover, trade and services jobs would remain dynamic, essentially the professions of care and services for people. It is worth noting that there are spheres with trends to decline - agriculture and public administration. At the contrary, the growing sectors are the industry, real estate, transports, trade, services to businesses, services to individuals, education and others.

Conclusion. France has a broad system of education, due to a great amount of investment in the State's budget. Indeed, the access to education has become a priority, which is taking more and more importance in the concerns of the European countries. French's education system has much common with other EU nations, due to the teacher qualification standards, the duration of studies and the skills assessed in national examinations. This permits to the students from the European Union to find a job quicker in any of the twenty-eight countries as the systems resemble one another. The foreigners can encounter difficulties working in the French market but they can appeal to the process of nationalization or still work in an industry connected with their home country.

\section{Список использованных источников}

1. Zeldin T. Higher Education in France, 1848-1940 // Journal of Contemprorary History, 1967, 2 (3), C.53-80.

2. Lehoux L., Morozova T.V., Safonova E.G. New era of UK/Irish GAAP//B сборнике Финансы, налоги и учет в странах дальнего и ближнего зарубежья: инновационные решения сборник научных трудов по материалам Международной научно-практической конференции. -2017. -С. 13-17.

3. Гордиенко М.С., Глубокова Н.Ю. Анализ налоговых поступлений в бюджеты муниципального уровня Российской Федерации в 2014 году // Ученые записки Российской Академии предпринимательства. 2015. C. 65-73

4. Tikhonov S.V. Embedding lattice actions in flows with multidimensional time // Sbornik: Mathematics. 2006. T. 197. № 1-2. C. 95-126.

5. Akhmadeev R.G., Bykanova O.A., Morozova T.V., Safonova E.G., Turishcheva T.B., Lehoux L. Evalution of financial and analytical activities of the biggest car makers of the Russian Federation // Jurnal Pengurusan. 2018. T. 54. C. 30079.

6. Golubtsova E.V., Maksimov D.A., Shafiev R.M. Marking of goods and the Eurasian common market // Baltic Rim Economies. 2019. № 1. C. 32.

7. Akhmadeev R.G., Kosov M.E., Bykanova O.A., Frumina S.V., Melnichuk M.V. Taxation of end consumption: effect on country economies and its characteristics//American Journal of Applied Sciences. 2017. T. 14. № 3. C. 381-391

8. Sigarev A.V., Dubovik M.V., Novikova E.S. The role of ingormation communications technology in the development of companies'bussiness strategies: the Russian experience // International Journal of Civil Engineering and Technology. 2018. T. 9. № 10. C. 1131-1139.

9. Osipov V.S., Bykanova O.A., Akhmadeev R.G., Kosov M.E., Bogoviz A.V., Smirnov V.M. External debt burden and its impact on the countries’ budgetary policy//Journal of Applied Economic Sciences. 2017. T. 12. № 2 (48). C. $342-355$.

10. Paul J.-J, Murdoch J.-J. Higher Education and Graduate Employment in France // European Journal of Education, 2000,35 (2), C. 179-187 


\section{Chloe Delen}

Student of France University IESEG School of Management

Email: chloe.delen@ieseg.fr

\section{Тетюренко Ангелина}

Студентка 4 курса, Факультет «Международная школа бизнеса и мировой экономики» Российский экономический университет имени Г.В.Плеханова, Российская Федераџия, г. Москва, 117997, Стремянньй пер., 36

E-mail: angelina.tetiourenko@gmail.com

\section{Глубокова Надежда Юрьевна}

к.э.н., доцент

кафедра бухгалтерского учета и налогообложение

Российский экономический университет имени Г.В.Плеханова, Российская Федерация, г.

Москва, 117997, Стремянный пер., 36

E-mail: glubokova@mail.ru

\section{ОБРАЗОВАТЕЛЬНАЯ СИСТЕМА ФРАНЦИИ И ВОЗМОЖНОСТИ КАРЬЕРНОГО РАЗВИТИЯ}

\footnotetext{
Аннотация. В статье рассматривается французская система образования. Авторы провели исторический обзор и показали особенности развития французского образования, с учетом оценки с другими европейскими странами и Российской Федерации. В исследовании обращено внимание на право женщин на образование. Кроме того, представлена характеристика образования на каждом из его этапов: от начальной школы, перехода в среднюю школу до средней школы и далее - САР. Французская система образования имеет много общего с другими странами ЕС, что позволяет студентам из ЕС быстрее найти работу в любой из двадцати восьми стран в связи с тем, что эти системы схожи друг с другом.

Переведено с помощью www.DeepL.com/Translator

Ключевые слова: прирост капитала, налогообложение, налоговые ставки, сравнительный анализ, налоговая система Германии
} 